\title{
The Impact of IFRS/IAS Adoption on Corporate Income Taxation in Ghana
}

\author{
Virgil Nbellah Abedana (Corresponding author) \\ Department of Accountancy, Tamale Polytechnic \\ P. O. Box 3 E/R, Tamale, N/R, Ghana \\ E-mail: vabedana13g@pentvars.edu.gh
}

\author{
Kwame B. Omane-Antwi \\ Graduate School, Pentecost University College \\ P. O. Box KN 1739, Kaneshie, Accra, Ghana
}

Alexander Owiredu

Department of Accounting, Pentecost University College

P. O. Box KN 1739, Kaneshie, Accra, Ghana

Received: February 22, 2016 Accepted: March 10, 2016 Published: June 01, 2016

doi:10.5296/ijafr.v6i1.9070 URL: http://dx.doi.org/10.5296/ijafr.v6i1.9070

\begin{abstract}
Studies in a multiplicity of reporting jurisdictions worldwide have revealed considerable divergence in the impact of IFRS/IAS adoption on taxation. There is minimal empirical study on the tax impacts or effects of reporting entities following the transition from GNAS to IFRS by Ghanaian listed companies. The study therefore investigates the changes to corporate taxes, deferred tax and net tax assets (liabilities) using a sample of entities from the Ghana Stock Exchange over the period 2007 / 2006 to 2008 / 2007 which encompasses the move from GNAS to IFRS, particularly IAS 12.The research design was predominately quantitative in nature and cross-sectional in approach. The population for the study was all companies' listed (42 companies) on the Ghana Stock Exchange (GSE) as at December 2015. The study used a sample of 22 listed entities after deducting invalid search results, companies that previously did not use GNAS as well as not using Ghana Cedis as their currencies, delisted entities since 2007 and free zone entities. The adoption of IFRS/IAS led to a few more listed companies paying less taxes and majority not having any changes in their tax
\end{abstract}




\section{MInstitute Macrothink $_{\text {Int }}$}

International Journal of Accounting and Financial Reporting ISSN 2162-3082 2016, Vol. 6, No. 1

burdens following the restatement of accounts from GNAS into IFRS/IAS. Overall, the paired sample t-test of GNAS and IFRS on reported tax amounts showed no differences between IFRS and GNAS computed amounts. Largely, 90.1\% of firms observed did not report any changes to current tax assets. Whiles $94.5 \%, 86.4 \%$ and $59.1 \%$ of observations reported negative changes in deferred tax assets, current tax liabilities and deferred tax liabilities respectively. In terms of industry sectors, the manufacturing / trading industry saw a positive change of $13 \%$ in current year tax expenses burden whiles the financial / insurance / information technology industry reported a decrease of $13.3 \%$ in current year tax expenses liability.A further and in-depth longitudinal study could be done to study the trend of tax burdens as well as the pattern of effective tax rates of listed companies since the adoption of IFRS/IAS in Ghana since this one provide mixed impacts.

Keywords: IFRS/IAS adoption, Corporate Income Taxation, Impact on Taxes, Ghana

\section{Introduction}

The link between tax accounting and financial accounting is an intricate topic with various dimensions. It is a very dynamic area of study. One explanation for this is changes within financial accounting reporting on the international level. The most important change has been the adoption of International Financial Reporting Standards (IFRS) / International Accounting Standards (IAS) as the mandatory standard for consolidated accounts in listed companies. The adoption of IFRS / IAS has become a global phenomenon. Globally, various trade blocks or countries have obliged all their listed companies to prepare their consolidated financial statement to conform to IFRS / IAS. For example, the European Union (EU) passed an EC Regulation (Regulation No. 1606/2002) on July 19 ${ }^{\text {th }}$, 2002 that requires all listed EU companies, to from $1^{\text {st }}$ January 2005 onwards prepare their consolidated financial accounts conforming to IFRS / IAS.

Within Africa alone, there are several countries that have equally adopted IFRS /IAS since 2005 and more are still on the path of adopting same. These adoptions however give sovereign states the option to require or permit IFRS / IAS reporting in corporate financial accounts (Larson \& Street, 2004). In Ghana, the adoption of IFRS / IAS took-off in January 2007 but due to implementation challenges, effectively was implemented in the 2008 financial year. The adoption of this international harmonised standard has raised several questions and concerns regarding its impact on the tax burden of reporting entities. The aim of this paper is therefore to examine the impact of the adoption of IFRS / IAS particularly IAS 12 on listed companies tax burdens and related corporate tax elements. It also sought to determine and analyses the effects of IFRS / IAS 12 on the accounting numbers reported in the transitional year of the financial statements of listed companies. This study will most probably maintain the current tax competitive positions of Ghana in the community of nation globally. The expected broadening of the tax base could constitute an opportunity to reduce the corporate income tax rate without changing the overall effective burden. 


\subsection{Problem Statement}

In Ghana, the requirement for transitioning to IFRS / IAS were championed by the Institute of Chartered Accountants, Ghana (ICA-G) which wholly adopted the IFRS / IAS as issued by the International Financial Reporting Standard Board. Reporting in the transitioning year required IAS 1 - which is about disclosing the impact of adopting IFRS / IAS; and IFRS1 which is also about the first-time adoption disclosures requirement. The rationale of IAS 1is to inform users of accounting information on how listed companies transitioning to IFRS/ IAS was being managed and to specify the expected date of adoption. Listed entities also had to elucidate the key differences in accounting policies that were expected to arise from adopting IFRS/IAS and the potential impact of the change on the financial reports. IFRS 1 laid down the disclosure requirements for entities on transition to IFRS/IAS. IFRS companies in the year of adoption were required to provide reconciliations of equity and earnings as reported under the previous GNAS and IFRS/IAS at both the date of transition and the reporting date. Ample detail was essential to enable users to understand the material adjustments to the Financial Position and to the income statement.

It is arguably true that the adoption of IFRS would alter the arrangement and content of financial statements. It was also predictable that the adoption of a new set of financial accounting reporting standards may modify the reported results and financial position of reporting entities (Hickey et al., 2003).Although the financial impact from the adoption of IFRS would differ for each company, commentators highlighted the areas where the effects were likely to be significant. Teixeira (2004)and Bradbury and van Zijl (2005) recognized the following reporting areas where the impact on a number of companies was expected to be major: (a) income tax, because of fundamental changes in the concepts and method for recognising deferred tax assets and liabilities; (b) property plant and equipment, where offsetting revaluation decreases and increases could no longer occur within an asset class; (c) employee benefits, revenue recognition and intangibles because there were no equivalent New Zealand standards; (d) financial instruments, for which derivative financial instruments must be recognised at fair value and detailed rules applied to account for hedges; (e) business combinations, because of the change in accounting treatment for goodwill on consolidation; (f) agricultural assets, where fair value accounting was required; and (g) share-based payments transactions which were required to be recognised in the financial statements.

According to Vaughan (2004 and 2005) and Kwong et al. (2005), there was in addition speculation about the potential financial impact for specific listed companies. Though there were a number of anticipated differences between IFRS / IAS and local GAAPs (GNAS) there were also a number of areas where treatment was expected to be similar; for example, in the measurement and recognition of inventories, and the depreciation on property, plant and equipment among others. In the mist of these observations, studies have been done in Belgium, New Zealand and Nigeria (Haverals, 2005; Rainsbury, San Diego \& Walker, 2010 and Samuel, Samuel \&Obiamaka, 2013; Faboyede, Oyewo, Fakile and Nwobu, 2014) to either determine or examine the financial impact of IFRS adoption on Taxation or tax burden of companies. There is however an absence of such study in respect of Ghana to examine or determine the impact of IFRS/IAS on corporate tax burdens and tax elements as reported in 


\section{Macrothink \\ International Journal of Accounting and Financial Reporting \\ ISSN 2162-3082 \\ 2016, Vol. 6, No. 1}

IAS 12.

\subsection{Objectives of the Study}

The general objective of this paper is to examine the impact of post-IFRS adoption on corporate income taxation in Ghana.

Specifically, to examine:

- the impact of IFRS/IAS on Corporate Taxes by Industries

- the Effects of IFRS (IAS 12) on Corporate Tax Elements of Current tax assets, deferred tax assets, current tax liabilities, deferred tax liabilities and current year tax expense.

- the differences between IFRS - IAS 12 and GNAS on Corporate Taxations

\subsection{Hypothesis of the Study}

From the forgoing research objectives the following hypothesis were set for testing.

$\mathrm{H}_{1}$ : There is no difference in the IFRS current tax assets as restated in the 2008/2007 financial statements and the GNAS current tax assets reported on the 2007 / 2006 financial statement.

$\mathrm{H}_{2}$ : There is no difference in the IFRS deferred tax assets as restated in the 2008/2007 financial statements and the GNAS deferred tax assets reported on the 2007 / 2006 financial statement.

$\mathrm{H}_{3}$ : There is no difference in the IFRS current tax liabilities as restated in the 2008/2007 financial statements and the GNAS current tax liabilities reported on the 2007 / 2006 financial statement.

$\mathrm{H}_{4}$ : There is no difference in the IFRS 2007 deferred tax liabilities as restated in the 2008/2007 financial statements and the GNAS deferred tax liabilities reported on the 2007 / 2006 financial statement.

\subsection{Significance of the Study}

The study examines the impact of a major regulatory adaptation in financial reporting by documenting Ghana's experience with the switchover from GNAS to IFRS/IAS. It extends the research of IFRS/IAS implementation to Ghana taxation system. The findings are of relevance to the accounting profession and regulators as they debate whether IFRS/IAS should be required for the preparation general purpose financial statements for small to medium-sized enterprises yet to be adopted. Furthermore, this research is expected to increase awareness of the impact of IFRS/IAS adoption on corporate income taxation among the accountancy and tax professionals in Ghana. It would also significantly serve as literature that would add to academic knowledge in the area of accounting standards and taxation for this specialised technical area of study globally. It will do this by enriching the literature base of the impact of IFRS/IAS adoption on corporate income taxation globally. 


\section{Literature Review}

\subsection{The Concept of International Financial Reporting Standards (IFRS)}

Basically, International Financial Reporting Standards (IFRS) or International Accounting Standards (IASs) are principles and rules for reporting financial information, as established and approved by the International Accounting Standards Board (IASB). Also according to Alistair (2010) IFRS are a sequence of accounting pronouncements published by the International Accounting Standard Board (IASB) to assist prepare financial statements throughout the world, to provide and present high quality, transparent and comparable financial information. IFRSs are issued by the International Accounting Standards Board (IASB), formerly known as International Accounting Standards Committee (IASC). According to Cordazzo (2007), the IAS/IFRS consist of a set of international accounting principles, the adoption of which aims at establishing clear rules within the European Union to draw up comparable and transparent annual reports and financial statements. Their adoption represents an essential element to obtain an integrated, competitive and attractive European capital market, which has impelled the European Commission to introduce this set of uniform accounting standards for listed EU companies preparing consolidated financial statements.

IFRS's are also principles, bases, conventions, rules and practices applied by an organisation through recognizing, selecting measurement basis for and presenting assets, liabilities, gains, losses and to shareholders funds. According to Nkundabanyanga, (2004) IFRS are accounting standards set up with an aim of harmonizing accounting procedure across the world. IAS one (1) requires an enterprise to select and apply appropriate accounting policies complying with IFRS to ensure that financial statements provide information that is relevant to the decision making needs of users and reliability in terms of fair presentation, prudent, complete and economic substance. In identifying whether an accounting policy has changed in an entity, it involves considering if any of the three aspects has changed; recognition-some items may be recognized as expenditure on developing new products or to be recognized as assets in the balance sheet, presentation-how something is presented in financial statements like why certain indirect costs appear in profits and loss account, measurement basis- the monetary aspects of the item in the financial statement such as the basis of the stock valuation say FIFO and LIFO.

\subsection{Impact of IFRS/IAS on Financial Statements}

Several studies in various parts of the world have analysed and examine the impact of IFRS/IAS on Financial Statements, (Stent, Bradbury \& Hooks, 2010; Blanchette, Recicot \& Sedzro, 2013); on companies performances (Rainsbury, San Diego \& Walker 2010); on taxation (Samuel, Samuel \& Obiamaka, 2013); on financial statements and ratios (Bharagava \& Shikha, 2013); on the value relevance of book value and earnings (Clarkson, Hanna, Richardson, \& Thompson, 2011); and on the tax burden of companies (Haverals, 2005). They all suggest that the adoption and implementation of IFRS/IAS has had a positive impact on entities, financial reporting and financial ratios as well as on the wider economic settings. Indeed as argued by Petreski, (2005), the effects or impact of IFRS/IAS adoption are 
multiple, positive and worthy of note.

Haverals, (2005) found that the impact of an IFRS/IAS-based tax accounting on the effective tax burden of Belgian companies is large and not uniform across sectors. Bhargava and Shikha, (2013), also found that there was variation in the financial ratios of profitability and liquidity. They argue that the variation is because of the reclassification among equity and liabilities and that the difference in the concept of recognizing revenue in the financial statements. According to Stent, Bradbury and Hooks, (2010), they also found that $87 \%$ of companies in New Zealand are affected by the adoption of NZ IFRS and for most entities; the impact of NZ IFRS is small. They also conclude that the impact has considerable effects on the common financial ratios used by users of accounting information.

Daske et al. (2008) and Li (2010) examined the impact of IFRS adoption on international capital markets. Daske et al. (2008) establish that entities adopting IFRS/IAS in the year of mandatory adoption saw large increases in market liquidity but mixed outcomes for the cost of capital. However, Li (2010) examined the effect of IFRS/IAS on the cost of equity in the European Union and conclude that mandatory adopters of IFRS/IAS experience significant reductions in the cost of capital in the years of mandatory adoption, but only in countries with strong legal enforcement.

Some other studies have examined the effects of IFRS adoption on accounting quality. Goodwin and Ahmed (2006) examined the impact of IFRS in Australia in relation to the size of entities. Smaller firms had fewer adjustments upon IFRS adoption and experienced increases in net income and equity. Larger firms had many adjustments in contrast, negligible increases to net income, and a decrease in equity. They concluded that the adoption of IFRS has been found to have modest impact on the accounting quality of smaller firms, and a larger impact on the accounting quality of larger firms. Similarly, Goodwin, Ahmed and Heaney (2007) found, that on an average, IFRS caused increases in liabilities and leverage ratio and decreases in equity and earnings. These findings are consistent with the results of Hung and Subramanyam (2007), which compared financial statement under IFRS/IAS and German GAAP by focusing on the detail financial statement effects of adopting IFRS /IAS in Germany.

Barth, Landsman and Lang (2008) found an increase in accounting quality ensuing from the implementation of IFRS/IAS in 21 countries that formerly used domestic GAAP. They concluded that firms that prepare their financial statements under IFRS/IAS are exposed to less earnings management, more timely recognition of losses, and more value relevance of accounting amounts than those companies using only domestic GAAP. They also concluded that the quality of accounting information is higher for firms that apply IFRS/IAS than for those that do not. Further information regarding the impact of IFRS adoption on financial statements comes from studies that extended the analysis to common financial ratios (Stent, Bradbury and Hooks 2010). Stent et al. (2010) found that adoption of IFRS in New Zealand led to a significant increase in liabilities and a decrease in equity for private sector entities. The reasons for the variation were the adjustments to income taxes, employee benefits and financial instruments. This paper tends to examine the impact of IFRS/IAS on corporate 
income taxation in Ghana. It will also make an analysis of the impact of IFRS/IAS on corporate tax elements by making use of financial statement reports of listed companies on the Ghana stock exchange.

The consolidated financial statements as per GNAS are compared with the consolidated financial statements under IFRS/IAS. Some selected tax elements have been analysed to indicate the differences between two sets of statements. The figures in the Financial Position Statement and the Income Statements have been completely drawn from the annual report of the companies. All figures are related to the period ending 31st December 2007 and 2008.

\subsection{The Effects / Impact of IFRS Adoption on the Taxation of Companies}

International accounting literature provides evidence that IFRSs/ IAS improve accounting quality and potentially reduce the cost of equity capital (e.g. Barth et al., 2006; Bushman, Piotroiski \& Smith, 2006; Daske, Hail, Leuz \& Verdi, 2008). However the adoption of IFRSs/IAS has raised several questions and concerns, especially regarding its impact on tax accounting and vice versa. According to Duhanxhiu and Kapllani (2012), IFRSs/IAS are formulated to achieve the objectives of financial reporting including providing information that is useful to investors, creditors and analysts in making rational investment and credit decisions. Tax rules (e.g. income tax law) are formulated, in part, to encourage certain kinds of behavior by taxpayers on the premise that such behavior is good for the economy as a whole. So, contrary to financial accounting, tax accounting generally is seen to serves only one user, in this case the government (GRA officials).

Although IFRS/IAS are now commonly used as the reporting standard for financial accounts, in some other countries tax authority still required businesses to prepare financial report based on national GAAP for taxation purpose. In some other countries, which are still in the process toward IFRS/IAS implementation, there appear to be indecision as to whether they will use IFRS/IAS financial report or GAAP-financial report as a basis for calculating taxation income. According to Eberhartinger and Klostermann (2007), usage of IFRS/IASfinancial report for tax calculation will simplify reporting process and minimize compliance cost. Although usage of IFRS/IAS as tax basis will increase Effective Tax Rate (ETR) in some specific industry (Haverals, 2007) it might not do same in other industries. Leuz, Lins and Warnock, (2009) theorized that the main impact of the transition to IFRS/IAS would be concentrated with firms, who would have to respond to changes in both financial reporting rules and also tax regulations.

A conversion to IFRS/IAS may also affect the calculation of the parent's basis in its foreign subsidiaries and thereby influence cash repatriation plans. Proper planning should involve an analysis of the tax results both before and after an IFRS conversion. Also, to the extent the realization of a tax benefit depends on the pre-tax statutory books, consideration should be given to the desirability and timing of conversion for individual legal entities and jurisdictions. Finally, IFRS/IAS conversion is a global occurrence. As IFRS/IAS standards steps in for GAAP; there is arguably change in impacts for all entities in jurisdictions filing under IFRS/IAS. To the extent that local tax rules are based on accounting standards, there may be a corresponding impact on the tax attributes of a subsidiary in that jurisdiction. Any 


\section{Mll Macrothink}

International Journal of Accounting and Financial Reporting ISSN 2162-3082 2016, Vol. 6, No. 1

time a local or global accounting standard changes, there is a potential for a consequence on tax attributes of the firms in those jurisdictions. It is generally understood that the adoption of IFRS/IAS would change the structure and content of financial statements.

Barth et al. (2008) also suggest an increase in accounting quality resulting from the adoption of IFRS/IAS in 21 countries that previously used domestic GAAP. They concluded that corporations that prepare their financial statements under IFRS/IAS are exposed to less earnings management, more timely recognition of losses, and more value relevance of accounting amounts than those entities using only domestic GAAP. They also concluded that the quality of accounting information is higher for firms that apply IFRS/IAS than for those that do not.

There is minimal empirical study on the tax impacts or effects of reporting entities following the transition from GNAS to IFRS by Ghanaian companies. The study therefore investigate the changes to income tax, deferred tax and net tax assets (liabilities) using a sample of entities from the Ghana Stock Exchange over the period 2007 / 2006 to 2008 / 2007 which encompasses the move from GNAS to IFRS, particularly IAS 12. The research analyses the variables that influence the change in income tax, deferred tax and net tax assets (liabilities) due to the implementation of IFRS/IAS, including assets revaluation, unrecognized deferred tax assets, industry sectors.

\section{Research Methodology}

The research design was predominately quantitative in nature. This is so because it involved the extraction of corporate tax figures from annual reports and financial statements to process for results that meet the objectives of the study. It was also cross-sectional in approach. The population for the study was all companies listed on the Ghana Stock Exchange (GSE) as at December 2015. Twenty two listed unit trust and funds were excluded as the financial impact of IFRS/IAS would be quite diverse for these entities. Six listed entities that provided invalid search results for the related years under consideration were excluded, five companies that did not report previously under GNAS as well as companies that are not in Ghana Cedis were also excluded. Seven companies that were not listed at the time and two companies in financial difficulties and delisted since 2008 and 2013 were also excluded. One other entity that is under free zone and as a result has a tax incentive spanning from 2004 to 2014 was also excluded.Two other companies that disclosed insufficient data were rejected, resulting in a sample of 22 companies.

Financial statement data on corporate taxes, current tax assets, current tax liabilities, deferred tax assets and deferred tax liabilities reported under GNAS and IFRS/IAS were collected from annual reports. Corporate taxes data was obtained from the Annual Reports Ghana Archive. To capture the effects of IFRS/IAS adoption on financial statements, accounting figures computed under IFRS are compared, at a company level, with accounting figures computed under GNAS at the same date or period. IFRS 1 specifies the requirements for an entity that adopts and applies IFRS/IAS for the first time to prepare accounts in a certain outlook. This includes the requirement that an entity's first financial statements in IFRS/IAs include at least one year of comparative information restated to IFRS. This rule allows for the 
comparison of accounting figures in IFRS/IAS and GNAS for the year prior to the transition to IFRS/IAS. As a result, the comparison between IFRS and GNAS can be done using the original 2006/2007 financial statements in GNAS and the 2007 / 2008 statements retrospectively adjusted to IFRS/IAS which are presented as part of financial statements published in 2008. IFRS 1 also requires an entity to explain how the transition from GNAS to IFRS/IAS affected the reported financial position, financial performance and cash flows. In practice, this is done in a transition note attached to financial statements which contains reconciliations and explanations. The present study uses these transition notes to identify differences between financial statement figures derived under GNAS and IFRS/IAS.

The data collection followed a three-step process: first, IFRS/IAS figures (2007 restated) which correspond to comparative figures presented for the year prior to the change were collected from IFRS/IAS financial statements (i.e. financial position statement, income statement, statement of comprehensive income/loss, cash flow statement and notes). Second, GNAS figures were collected from original GNAS statements (published in the year prior to the adoption) for the same date and period. Third, the reconciliations and explanations provided in the transition notes to IFRS/IAS statements were used to further detail differences observed in the values collected through steps 1 and 2, and categorize them into the accounting adjustments identified. In addition to the figures from financial statements, non-financial information was collected from the notes to the accounts.

\section{Data Analysis and Discussions}

The data are discussed and analyse in accordance with the following headings: impact of IFRS/IAS on corporate taxes by industries, impact of IFRS/IAS adoption on corporate taxation in Ghana, the effects of IFRS/IAS (IAS 12) on corporate tax elements, and test of differences between IFRS/IAS (IAS 12) and GNAS standard on Taxations. These results are discussed in sections. The first section is concerned with descriptive statistics of both GNAS financial statement reports and IFRS/IAS financial statements reports. Here, the descriptive statistics focus on proportion of entities either reporting zero balance or non-zero balance in all the corporate tax elements as use in this study. Section two looks at the magnitude of the differences and the direction of changes following the IFRS/IAS adoptions. Table 1 and 2 reports the descriptive statistics of the firms' sampled. Table 1 presents reports on the GNAS figures as this is the base from which a measure of the difference due to the adoption of IFRS can be done.

\subsection{Impact of IFRS on Corporate Taxes by Industries}

From an examination of the accounts as shown in Table 2 and 3, there were changes in some of the corporate tax elements as in GNAS and IFRS/IAS accounts. The changes were further analyses into industry sector to investigate which industry had a greater magnitude of change as a result of the adoption of IFRS by the sample firms. From the calculations done by the authors, the financial / information technology sector saw a reduced mean magnitude of change of $13.3 \%$ in their current year tax expenses, the manufacturing / trading sector on the other hand saw an increase mean magnitude of change of $13 \%$ in their current year tax expense whiles the petroleum / oil sector saw no change in magnitude following the adoption 
of IFRS/IAS. The financial / IT sector saw this reduction as a result of fair value valuation of its assets and financial instruments which led to a drastic reduction in deferred tax assets culminating in a reduction in current tax liabilities as well. Deferred tax assets are noted to account for the amounts of income taxes recoverable in future periods that arise from temporary book-tax differences, i.e., differences between the book value of a liability and its tax base that will result in tax deductible amounts when the book value of the liability is settled.

On the other hand, the manufacturing / trading sectors saw a mean increase in magnitude of its current year tax expense as reflected in the income statement because of a huge increase by one entity deferred tax liabilities. An example of this deferred tax liability is where an accelerated depreciation of assets led to a deferred tax expense following the adoption of IFRS. Deferred tax liabilities are also noted to account for the amounts of income taxes payable in future periods that arise from temporary book-tax differences, i.e., differences between the book value of an asset and its tax base that will result in taxable amounts when the book value of the asset is recovered.

In terms of the direction of changes by industries, the effects revealed that the manufacturing / trading sector had a substantial number $(88.9 \%)$ of entities that never saw any change in their current year tax expense followed by the financial / IT sector which saw a $70 \%$ of entities having not experienced any change to their current year tax expenses following the adoption of IFRS. The financial / IT sector experienced a 30\% of entities having their current year tax expense been reduced following the restatement of the 2007 financial year statements into IFRS as reflected in the 2008 / 2007 annual reports. Widely spread is the observation that only the manufacturing / trading sectors saw an increase of $22.2 \%$ of sample entities having experience an increase in their current year tax expense for the restatement of figures into IFRS.

From the observed data gathered and analysed, the petroleum / oil sectors saw an overwhelming $100 \%$ no change in all the corporate tax elements except for deferred tax liabilities which saw a $50 \%$ of sampled entities reporting increases following the adoption of IFRS. Overall, the maximum and minimum values indicate that the effect of IFRS on financial / IT sector in respect of deferred tax liabilities can be quite substantial for firms in this category. For example the range for deferred tax liabilities with regard to financial / IT sector is $5.177(4.177-(-1.000))$. However, for the rest of the other corporate tax element across industries, the maximum and minimum values were seen to be narrow thereby implying that effect of IFRS on sample firms were not quite substantial or impactful. The industry sector analysis is presented in table 1 . 


\section{Mll Macrothink Institute}

Table 1: Industry impact analysis of IFRS adoption

\begin{tabular}{|c|c|c|c|c|c|c|c|c|c|c|c|c|c|c|c|}
\hline & CYTE & CTA & DTA & CTL & DTL & CYTE & CTA & DTA & CTL & DTL & CYTE & CTA & DTA & CTL & DTL \\
\hline \multicolumn{16}{|c|}{ Magnitude of change } \\
\hline Maximum & .000 & .000 & .000 & .000 & 4.177 & 1.153 & .000 & .000 & .000 & .233 & .000 & .000 & .000 & .000 & 7.114 \\
\hline Mean & -.133 & .000 & -.09 & -.10 & .218 & .130 & .000 & .000 & .111 & .026 & .000 & .000 & .000 & .000 & 3.557 \\
\hline Positive (+) & 0 & 0 & 0 & 0 & 10 & 22.2 & 0 & 0 & 0 & 11.1 & 0 & 0 & 0 & 0 & 50 \\
\hline Negative (-) & 30 & 0 & 10 & 20 & 20 & 0 & 0 & 0 & 11.1 & 0 & 0 & 0 & 0 & 0 & 0 \\
\hline No change & 70 & 100 & 90 & 80 & 70 & 77.8 & 100 & 100 & 88.9 & 88.9 & 100 & 100 & 100 & 100 & 50 \\
\hline \multicolumn{16}{|c|}{ Note: ${ }^{a}$ The magnitude of change is estimated as (IFRS/GNAS) - 1} \\
\hline
\end{tabular}

\subsection{Impact of IFRS Adoption on Corporate Income Taxation in Ghana}

From the data collected from the 2007 / 2006 financial statements which relates to GNAS, there are $95.5 \%(21 / 22)$ of firms that have reported non-zero balance for current year tax expenses. The maximum current year tax expense reported is GHф35,210,822 which comparatively is an outlier. The mean current year tax expense reported is $\mathrm{GH} \notin 3,387,102.64$, indicating the data is skewed by a few observations. There are three companies that have current year tax expense of over GHф5,000,000. The rest of the entities are ranging between hundreds of Ghana Cedis and three million Ghana Cedis. There are 40.9\% (9/22) of the observed firms that reported current tax assets with mean score of GHф98,505.09. The maximum current tax asset is $\mathrm{GH} \notin 753,000$ and the minimum is $\mathrm{GH} \phi 0$. The majority of firms reporting current tax assets were the financial / information technology businesses.

Entities reporting current tax asset otherwise known as income tax receivable is consistent with the theory that use of money interest is an incentive to estimate and pay tax at the correct level or overpaying it. From the GNAS financial statement again, there are 90.9\% (20/22) with no deferred tax assets and 63.6\% (14/22) of companies with deferred tax liabilities. The small number of firms reporting deferred tax assets confirms the earlier results of only a $4.5 \%$ $(1 / 22)$ reporting zero current year tax expense. By this it implies that there are no carry over losses or tax credits which leads to higher deferred tax assets. The maximum of $\mathrm{GH} \notin 3,283,591$ is reported by only one company for deferred tax asset while the minimum of $\mathrm{GH} \not 0$ is reported by twenty firms.

The mean deferred tax asset is GHф193,345.05. This is compared to a mean of GH $\notin 677,295.09$ reported for deferred tax liabilities for the same period. The maximum 
deferred tax liabilities was however reported to be lower $(\mathrm{GH} \notin 2,960,000)$ as against that of the results of deferred tax asset. Both deferred tax assets and deferred tax liabilities however had $\mathrm{GH} \phi 0$ as their minimum scores. Overall, there are a greater number of entities reporting deferred tax liabilities than deferred tax assets as well as those reporting non-zero balances for current year tax expense. Also, there is slightly a difference of one business reporting current tax liabilities as against those reporting current tax assets.

Table 3 presents report on the corporate taxes of the sample firms as restated from the 2007/2006 financial statement into the 2008 / 2007 financial statements in IFRS/IAS figures. From the post-IFRS (i.e. GNAS amounts restated in IFRS in the 2008/2007 financial year), there are still $95.5 \%(21 / 22)$ of firms that have reported current year tax expense. The mean however is $\mathrm{GH} \phi 1,784,452.09$ with the maximum also reducing to $\mathrm{GH} \phi 10,136,000$. The maximum score reduction follows the restated amount of the prior outlier of one of the company to an amount far lower than in the 2007/2006 financial year. The mean amount of current year tax expense reduced drastically due to the changes in the outlier in GNAS reducing to GH $\notin 20,487$ in the IFRS/IAS restated amounts. There are 50\% (11/22) of entities with current tax assets with mean amounts of GHф165,509.41. The maximum current tax asset is $\mathrm{GH} \phi 1,163,000$. There are also $40.9 \%$ (9/22) of listed companies that reported current tax liabilities with mean of $\mathrm{GH} \phi 135,352.64$ and a maximum amount of GH $\phi 1,494,000$. Both current tax assets and current tax liabilities reported $\mathrm{GH} \varnothing 0$ as their minimum amounts and no entity reported negative amounts.

From the observation again, the number of companies of the IFRS/IAS restated financial statement that reported deferred tax assets are $13.6 \%(3 / 22)$ with mean amount of GH $\notin 57,945.59$. The maximum amount however reported is GH $\varnothing 970,000$. The numbers of entities that reported deferred tax liabilities were also $77.3 \%(17 / 22)$ with a mean amount of GH $ф 982,192.68$ and a maximum amount of GHф6,759,000. Like current tax assets and current tax liabilities, both deferred tax assets and deferred tax liabilities also had GH $c 0$ as their minimum amounts reported. There were no negative amounts reported for all the corporate tax elements as used in this study. Again as in the case of pre-IFRS restated amount, there are a greater number of listed companies reporting deferred tax liabilities than those reporting deferred tax assets as well as those reporting non-zero amounts for current year tax expense.

However, per post-IFRS restated amount, there are a greater number of entities reporting current tax assets than those reporting current tax liabilities by a difference of two observations. It must be noted that it is normal for entities to report $\mathrm{GH} \phi 0$ amounts for various corporate tax elements as seen in most of the observations in this case. For example, the current year tax expense in this circumstance reported $\mathrm{GH} \not 0$ as minimum amount for current year tax expense because one entity reported a net loss in the 2007 financial year and as such did not have to incur income tax expenses as per the internal revenue Act 2000, (ACT 592). The details of these are shown on table 2 and 3. 
Table 2: Descriptive statistics of GNAS financial Statement in GHc

\begin{tabular}{lllll}
\hline & N Minimum & Maximum & Mean & Std. Deviation \\
\hline CYTE & 220 & $35,210,822$ & $3,387,102.64$ & $7,564,545.92$ \\
CTA & 220 & 753,000 & $98,505.09$ & $213,777.95$ \\
DTA & 220 & $3,283,591$ & $193,345.05$ & $720,464.77$ \\
CTL & 220 & $31,579,631$ & $1,584,567.09$ & $6,710,631.15$ \\
DTL & 220 & $2,960,000$ & $677,295.09$ & $1,031,633.85$ \\
\hline
\end{tabular}

Source: Companies 2007/ 2006 Annual Reports, Author's Own Calculation

CYTE - Current Year Tax Expense

CTA - Current Tax Asset

DTA - Deferred Tax Asset

CTL - Current Tax Liability

DTL - Deferred Tax Liability

Table 3: Descriptive Statistics of IFRS financial statement in GHc

\begin{tabular}{cccccc}
\hline & N & Minimum & Maximum & Mean & Std. Deviation \\
\hline CYTE & 22 & 0 & $10,136,000$ & $1,784,452.09$ & $2,617,572.01$ \\
CTA & 22 & 0 & $1,163,000$ & $165,509.41$ & $310,137.29$ \\
DTA & 22 & 0 & 970,000 & $57,945.59$ & $213,484.48$ \\
CTL & 22 & 0 & $1,494,000$ & $135,352.64$ & $386,599.08$ \\
DTL & 22 & 0 & $6,759,000$ & $982,192.68$ & $1,662,969.47$ \\
\hline
\end{tabular}

Source: Companies 2008/ 2007 Annual Reports, Author's Own Calculation

\subsection{The Effects of IFRS (IAS 12) on Corporate Tax Elements}

From an examination of table 2 and table 3, it can be seen that there are few changes in the corporate tax obligations of the sample firms. A further analysis of the changes is presented in 
table 4. Mear, (2011) compared the number and percentages of income tax elements in respect of direction of changes comprehensively but did not report on the magnitude of changes of those corporate tax elements. However, in this study as can be seen in table 4, the researchers did an analysis of the magnitude of changes as well as the directions of changes. The first part of table 4 reports the magnitude of change in aggregate of all sample entities corporate taxes element due to the adoption of IFRS/IAS. It is measured as IFRS/IAS reported corporate taxes elements divided by GNAS reported corporate taxes elements minus one (IFRS / GNAS - 1). In this analysis, the study compared the 2007 / 2006 financial statements using GNAS to the 2008 / 2007 financial statements as restated in IFRS which is expected to have incorporated other adjustments as per IAS 12. The researchers then followed it with the discussion of the changes that are observed as directly being related to the change from GNAs to IFRS in the IFRS reconciliation notes.

From the comparison of the 2007/2006 and 2008/2007 financial statement, the mean magnitude of change in current year tax expense due to the adoption of IFRS is -0.7 percent where as the mean magnitude of change in deferred tax liability due to the adoption of IFRS is 44.3 per cent. The $-0.7 \%$ implies that on average, the sample firms' current year tax expenses reduced by a $0.7 \%$ in the restated amounts using IFRS/IAS. The little negative change in magnitude of change for current year tax expense is seen as a result of most of the sample entities adopting IFRS/IAS but not effecting IAS 12 in the restated year figures as seen from the reconciliation notes of the accounts. By this, it implies that most firms still used GNAS standard on taxation to prepare the restated amounts in the 2008 / 2007 financial statements.

The second part of table 4 reports the number of increases, decreases and stability in the corporate tax elements due to the adoption of IFRS/IAS. The adoption of IFRS resulted in a no change in current year tax expense for 77.3 percent (17/22) of the listed companies, a decrease for 13.6 percent of the listed entities and 9.1 percent showed increases. The data indicate that $22.7 \%(5 / 22)$ of the listed companies reported a change in their current year tax expense. Of this percentage, there are slightly more listed entities at the decrease $(-13.6 \%)$ than the increase $(9.1 \%)$. These changes are predominately due to the deferred tax assets account that reported $11.1 \%(1 / 22)$ decreases. The mean magnitude of change in deferred tax assets was a $-4.5 \%$. The decrease is in part justified as being due to changes in the recognition criteria for deferred taxes under IFRS/IAS as against GNAS.

The net effect of this is that even though 13.6 percent of the sampled firms had their overall current year tax expense obligation reduced, the overall aggregate of that reduction in value is only 0.7 percent as can be seen from table 4 . However, the maximum and minimum values indicate that the effect of IFRS/IAS can be quite substantial for some firms especially in the case of current year tax expenses and deferred tax liabilities. For example, the range is 2.152 $(1.153-(-.999))$ for current year tax expense and $8.114(7.114-(-1.000))$ for deferred tax liabilities.

The data gathered also revealed that the largest impact of IFRS/IAS is for deferred tax assets, where 90 percent of observations (20/22) report a decrease in deferred tax assets and 4.5 


\section{Mll Macrothink}

International Journal of Accounting and Financial Reporting

ISSN 2162-3082 2016, Vol. 6, No. 1

percent report both increases and no change in deferred tax assets. The impact of IFRS/IAS is not widespread as 59 percent (13/22) of firms sample were unaffected by the adoption of IFRS/IAS. Invariably, only 41 percent of sample firms were affected in one way of increase or decrease as a result of adopting IFRS/IAS. They were not widely affected because, as can be seen from the notes from the annual reports, most of the firms though adopted IFRS/IAS and restated the prior year figures in IFRS/IAS; they did not adopt IAS 12 as from IFRS/IAS but rather still use income taxes standard from the GNAS. Significantly is a zero percent decrease to current tax assets as well as a zero percent increases in current tax liability. Overall, the impact of IFRS/IAS significantly decreases deferred tax assets, current tax liabilities and deferred tax liabilities.

The change in current year tax expenses, current tax assets and current tax liabilities is a matter of concern as these elements represents income tax payable to or receivable from the GRA. Unless otherwise state, a change in presentation requirement should not bring about any effect on the amounts payable or receivable on these tax elements following the adoption of IFRS/IAS. However, there were changes noticed in this study. One explanation for these changes to corporate tax elements is that per GNAS, the entities were offsetting these corporate tax elements. This is evident in the data observed, as whenever an entity reported deferred tax assets, that entity did not report deferred tax liability. This was however absent in the restated year financial statement as those entities that reported deferred tax assets also reported deferred tax liabilities. IFRS/IAS provides improve guidance on offsets which may have altered income tax elements amounts presentation on the financial statements. One other explanation is that tax on losses carried forward are included in current income tax receivable (current tax assets) pre-IFRS and with the additional definitions given in IAS 12 under IFRS, they are then move to deferred tax assets post-IFRS/IAS.

The mean magnitude change in deferred tax assets is in the minority due to the absence of tax losses or credits amount reported by any entity in the restated year of 2008 / 2007. Consistent with Ernst and Young, (2004), deferred tax liabilities increases due to the adoption of IFRS but however deviates by decreasing in respect of deferred tax assets as the data reported a magnitude decrease change of $4.5 \%$ in deferred tax assets. This is due to a sharp reduction in the current year tax expense on one observation in the restated year. Equally consistent with Stent et al., (2010), is the case that the increase is considerably larger for tax liabilities (especially deferred tax liabilities) than tax assets.

Overall, there are $77.3 \%$ of entities that did not report any changes to current year tax expenses and $90.1 \%$ in current tax assets in restating GNAS amounts into IFRS/IAS amounts as reported by sample listed firms in Ghana. There is however reported changes in deferred tax assets, current tax liabilities and deferred tax liabilities of 94.5\%, 86.4\% and 90.0\% respectively. Noteworthy to add is that, these changes were in the negatives implying deferred tax assets, current tax liabilities and deferred tax liabilities reduced when restated into IFRS/IAS from GNAS using the same transactional data. 
Table 4: Descriptive Statistics of impact of IFRS / IAS

\begin{tabular}{|c|c|c|c|c|c|}
\hline & CYTE & CTA & DTA & CTL & DTL \\
\hline \multicolumn{6}{|c|}{ Magnitude of Change $^{a}$} \\
\hline Minimum & -.99942 & .0000000 & -.99855 & -1.00000 & -1.00000 \\
\hline Maximum & 1.15285 & .0000000 & .000000 & .000000 & 7.11405 \\
\hline Mean & -.0070127 & -.000000 & -.0453889 & -.0909217 & .4330465 \\
\hline Std. Deviation & .33901098 & -.000000 & .21289263 & .29412055 & 1.77259010 \\
\hline \multicolumn{6}{|c|}{ Direction of change $(\%)$} \\
\hline Positive & 9.1 & 9.1 & 4.5 & 0 & 31.8 \\
\hline No Change & 77.3 & 90.1 & 4.5 & 13.6 & 9.1 \\
\hline Negative & 13.6 & 0 & 90.0 & 86.4 & 59.1 \\
\hline \multicolumn{6}{|c|}{ Note: ${ }^{\mathrm{a}}$ The magnitude of change is estimated as (IFRS/GNAS) -1} \\
\hline
\end{tabular}

Source: Companies 2007/2006 and 2008/2007 annual reports, authors' own calculations

\subsection{Test of Differences between IFRS - IAS 12 and GNAS Standard on Taxations}

To advance the examination of the impact of IFRS/IAS adoption on corporate income taxation elements as used in this study, the study carried out a test for difference and significance (if any). This was made to demonstrate whether the IFRS - IAS 12 gives an improved corporate tax elements amount as against the GNAS standard on taxation following the adoption of IFRS/IAS in Ghana. A pair sample test for independence was useful here because the variables of the corporate tax elements has been measure in two different accounting standards thus the GNAS and IFRS /IAS. It is therefore the objective of the study to investigate whether the IFRS financial statements gives improve corporate tax element figures than the GNAS financial statements.

Also, will the IFRS/IAS financial statement give a superior tax expense to the firms which invariably are revenue to the government? The pair sample t-test was performed here because the study sought to determine whether the sample firms differ on GNAS and IFRS/IAS in respect of their tax obligation to the tax authority. Besides, the data observed were drawn 


\section{MInstitute Macrothink $^{m}$}

International Journal of Accounting and Financial Reporting ISSN 2162-3082 2016, Vol. 6, No. 1

from the same transactional activities but only reported in two diverse accounting standards. The analyses are group into hypotheses set up in respect of the four corporate tax elements (current tax asset, current tax liabilities, deferred tax assets and deferred tax liabilities) as use in this study.

$\mathrm{H}_{1}$ : There is no difference in the IFRS current tax assets as restated in the 2008/2007 financial statements and the GNAS current tax assets reported on the 2007 / 2006 financial statement.

The first hypothesis suggests that there would not be any differences in current tax assets amounts as reported by IFRS 2008/2007 restated amounts and GNAS financial statements reported amounts of sample firms. Once again, a paired-samples t-test was conducted to evaluate the tax impact of the adoption of IFRS on current tax assets amounts. There was a statistically significant increase in current tax assets amount from GNAS $(M=$ $\mathrm{GH} \notin 98,505.09, \quad S D=\mathrm{GH} \notin 213,777.95)$ to IFRS $(M=\mathrm{GH} \notin 165,509.41, \quad S D=$ $\mathrm{GH} \notin 310,137.29), t(21)=-1.24, p=.229$ (two-tailed).

The mean increase in current tax assets was $\mathrm{GH} \phi-67,004.32$ with a $95 \%$ confidence interval ranging from $\mathrm{GH} \phi-179,444.52$ to $\mathrm{GH} \notin 45,435.88$. Once again, following from Cohen (1988) guidelines of interpretation, the p-value of .229 indicates a large effect size. Again, as usual, probabilities more than .05 indicate the null hypothesis fails to be rejected. At the $\alpha=0.01$ of significance there is no enough evidence to conclude that the adoption of IFRS will improved current tax assets as restated in the 2008/2007 financial statements. Thus the embracing of IFRS does not direct or indicates to business entities reporting more or less current tax assets.

$\mathrm{H}_{2}$ : There is no difference in the IFRS deferred tax assets as restated in the 2008/2007 financial statements and the GNAS deferred tax assets reported on the 2007 / 2006 financial statement.

The second hypothesis suggests that there would not be any differences in deferred tax assets amounts as reported by IFRS 2007 restated amounts in 2008 / 2007 financial statements and GNAS financial statements reported amounts of sample firms. Once more, a paired-samples t-test was conducted to assess the tax impact of the adoption of IFRS on deferred tax assets amounts. There was a statistically significant decrease in deferred tax assets amount from GNAS $(M=\mathrm{GH} \phi 193,345.05, S D=\mathrm{GH} \phi 720,464.77)$ to IFRS $(M=\mathrm{GH} \phi 57,945.59, S D=$ $\mathrm{GH} \notin 213,484.48), t(21)=.90, p=.378$ (two-tailed). The mean decrease in deferred tax assets was $\mathrm{GH} \not 135,399.46$ with a $95 \%$ confidence interval ranging from $\mathrm{GH} \phi-177,180.25$ to $\mathrm{GH} \notin 447,979.16$.

In line with Cohen (1988) guidelines of interpretation of pair sample t-test, the p-value .378 indicated a large effect size. Usually again, probabilities more than .05 indicate the null hypothesis fails to be rejected. In this case, the probability is more than .05 hence it can be concluded that there is no difference in the IFRS deferred tax assets as restated in the 2008/2007 financial statements and the GNAS deferred tax assets reported on the 2007 / 2006 financial statement. Thus the acceptance of IFRS does not suggest that business entities reports more or less deferred tax assets.

$\mathrm{H}_{3}$ : There is no difference in the IFRS current tax liabilities as restated in the 2008/2007 


\section{MlMacrothink}

International Journal of Accounting and Financial Reporting ISSN 2162-3082 2016, Vol. 6, No. 1

financial statements and the GNAS current tax liabilities reported on the 2007 / 2006 financial statement.

The third hypothesis suggests that there would not be any differences in current tax liabilities amounts as reported by IFRS 2007 restated amounts in 2008 / 2007 financial statements and GNAS financial statements reported amounts of sample firms. Again, a paired-samples t-test was conducted to appraise the tax impact of the adoption of IFRS on current tax liabilities amounts. There was a statistically significant decrease in current tax liabilities amount from GNAS $(M=\mathrm{GH} \notin 1,584,567.09, S D=\mathrm{GH} \notin 6,710,631.15)$ to IFRS $(M=\mathrm{GH} \phi 135,352.64, S D=$ GH $\notin 386,599.08), t(21)=1.01, p=.324$ (two-tailed). The mean decrease in current tax liabilities was $\mathrm{GH} \phi 1,449,214.46$ with a $95 \%$ confidence interval ranging from $\mathrm{GH} \phi-$ $1,532,408.81$ to $\mathrm{GH} \phi 4,430,837.72$.

Once more, in line with Cohen (1988) proposed guidelines of interpretation of pair sample ttest, the p-value .324 indicated a large effect size. Yet again, probabilities more than .05 will indicate that the null hypothesis is failed to be rejected. Yet in this case again, the probability is more than .05 hence it can be concluded that there is no difference in the IFRS current tax liabilities as restated in the 2008/2007 financial statements and the GNAS deferred tax assets reported on the 2007 / 2006 financial statement. Thus the implementation of IFRS does not lead to business entities reporting more or less current tax liabilities due to the implementation.

$\mathrm{H}_{4}$ : There is no difference in the IFRS 2007 deferred tax liabilities as restated in the 2008/2007 financial statements and the GNAS deferred tax liabilities reported on the 2007 / 2006 financial statement.

The fourth hypothesis again suggests that there would not be any differences in deferred tax liabilities amounts as reported by IFRS 2007 restated amounts in 2008 / 2007 financial statements and GNAS financial statements reported amounts of sample firms. Once more, a paired-samples t-test was conducted to evaluate the tax impact of the adoption of IFRS on deferred tax liabilities amounts. There was a statistically significant increase in deferred tax liabilities amount from GNAS $(M=\mathrm{GH} \phi 677,295.09, S D=\mathrm{GH} \phi 1,031,633.85)$ to IFRS $(M=$ $\mathrm{GH} \phi 982,192.68, S D=\mathrm{GH} \phi 1,662,969.47), t(21)=-1.11, p=.278$ (two-tailed). The mean increase in deferred tax liabilities was GHф-304,897.59 with a 95\% confidence interval ranging from $\mathrm{GH} \not-874,092.68$ to $\mathrm{GH} \phi 264,297.50$.

Over again, in line with Cohen (1988) proposed guidelines of interpretation of pair sample ttest, the p-value .278 indicated a large effect size. Once more on this, probabilities more than .05 will indicate that the null hypothesis fails to be rejected. For the fourth time, the probability is more than .05 hence it can be concluded that there is no difference in the IFRS/IAS deferred tax liabilities as restated in the 2008/2007 financial statements and the GNAS deferred tax assets reported on the 2007 / 2006 financial statement. Thus the approval of IFRS does not lead to business entities reporting more or less deferred tax liabilities due to the implementation.

Generally, the adoption of IFRS and the restatement of GNAS computed corporate tax 


\section{I Macrothink}

International Journal of Accounting and Financial Reporting

ISSN 2162-3082

elements of the 2007 financial transactions in the 2008 / 2007 IFRS financial statement did not reveal any significant differences in the corporate tax elements amounts as restated. This was observed as a number of reported entities though, adopted IFRS, did not apply IAS 12 but rather applied GNAS standard on income taxation. Two of the corporate tax elements (deferred tax assets and current tax liabilities) shown decreases in their means amounts due to the restatement of GNAS computed amounts to IFRS/IAS restated amounts. The other two elements (current tax assets and deferred tax liabilities) showed increases in their mean amounts as a result of IFRS implementation.

Generally, all the corporate tax elements as used in this study indicated large effect size per Cohen (1988) proposed guideline of assigning meanings to the significant values of pair sample t-test. Cohen (1988) proposed rule for interpreting this values are: .01= Small effect, $.06=$ Moderate effect, $.14=$ large effect. This implies that from table 5 and table 6 , they both showed large impact / effect size due to the adoption of IFRS but were not significant in changes to the computed amounts. Hence, the failure to reject the four tested hypothesis on the significance of changes between the GNAS standard on taxation and IFRS -IAS 12. The whole analysis of hypothesis one to four is shown in table 5 and table 6.

Table 5: Paired Samples t-test Statistics

\begin{tabular}{|c|c|c|c|c|}
\hline & & Mean & N Std. Deviation & Std. Error Mean \\
\hline \multirow{3}{*}{ Pair 1} & GCTA & $98,505.09$ & 22 213,777.954 & $45,577.613$ \\
\hline & & & & \\
\hline & ICTA & $165,509.41$ & 22 310,137.291 & $66,121.493$ \\
\hline \multirow{3}{*}{ Pair 2} & GDTA & $193,345.05$ & $22720,464.768$ & $153,603.605$ \\
\hline & & & & \\
\hline & IDTA & $57,945.59$ & $22213,484.482$ & $45,515.044$ \\
\hline \multirow{3}{*}{ Pair 3} & GCTL & $1,584,567.09$ & $226,710,631.149$ & $1,430,711.368$ \\
\hline & & & & \\
\hline & ICTL & $135,352.64$ & $22386,599.076$ & $82,423.200$ \\
\hline \multirow{3}{*}{ Pair 4} & GDTL & $677,295.09$ & $221,031,633.847$ & $219,945.075$ \\
\hline & & & & \\
\hline & IDTL & $982,192.68$ & $221,662,969.466$ & $354,546.281$ \\
\hline
\end{tabular}

Source: Companies 2007/2006 and 2008/2007 annual reports, authors' own calculations

$\begin{array}{lll}\text { GCYTE } & - & \text { GNAS Current Year Tax Expense } \\ \text { ICYTE } & - & \text { IFRS Current Year Tax Expense } \\ \text { GCTA } & - & \text { GNAS Current Tax Assets }\end{array}$




\section{Macrothink \\ International Journal of Accounting and Financial Reporting \\ ISSN 2162-3082 2016, Vol. 6, No. 1}
ICTA - IFRS Current Tax Assets
GDTA - GNAS Deferred Tax Assets
IDTA - $\quad$ IFRS Deferred Tax Assets
GCTL - GNAS Current Tax Liabilities
ICTL - IFRS Current Tax Liabilities
GDTL - GNAS Deferred Tax Liabilities
IDTL - IFRS Deferred Tax Liabilities

Table 6: Paired difference Samples T - Test

\begin{tabular}{|c|c|c|c|c|c|c|c|c|}
\hline & \multirow[t]{2}{*}{ Mean } & \multirow[t]{2}{*}{ Std. Deviation } & \multirow[t]{2}{*}{$\begin{array}{l}\text { Std. Error } \\
\text { Mean }\end{array}$} & \multicolumn{2}{|c|}{$\begin{array}{l}95 \% \text { Confidence Interval of the } \\
\text { Difference }\end{array}$} & \multirow[t]{2}{*}{$\mathrm{t}$} & \multirow[t]{2}{*}{ df } & \multirow{2}{*}{$\begin{array}{l}\text { Sig. } \\
\text { (2-tailed) }\end{array}$} \\
\hline & & & & Lower & Upper & & & \\
\hline $\begin{array}{l}\text { Pair } 1 \\
\text { GCYTE-ICYTE }\end{array}$ & $1,602,650.545$ & $7,502,587.911$ & $1,599,557.117$ & $-1,723,810.58$ & $4,929,111.672$ & 1.002 & 21 & .328 \\
\hline $\begin{array}{l}\text { Pair } 2 \\
\text { GCTA-ICTA }\end{array}$ & $-67,004.318$ & $253,600.583$ & $54,067.826$ & $-179,444.52$ & $45,435.881$ & -1.239 & 21 & .229 \\
\hline $\begin{array}{l}\text { Pair } 3 \\
\text { GDTA-IDTA }\end{array}$ & $135,399.455$ & $705,000.494$ & $150,306.610$ & $-177,180.25$ & $447,979.162$ & .901 & 21 & .378 \\
\hline $\begin{array}{l}\text { Pair } 4 \\
\text { GCTL-ICTL }\end{array}$ & $1,449,214.455$ & $6,724,831.526$ & $1,433,738.899$ & $-1,532,408.81$ & $4,430,837.718$ & 1.011 & 21 & .324 \\
\hline $\begin{array}{l}\text { Pair } 5 \\
\text { GDTL-IDTL }\end{array}$ & $-304,897.591$ & $1,283,777.584$ & $273,702.301$ & $-874,092.68$ & $264,297.503$ & -1.114 & 21 & .278 \\
\hline \multicolumn{9}{|c|}{$\begin{array}{l}\text { Source: Companies 2007/2006 and 2008/2007 annual reports, authors' own calculations } \\
\text { GCYTE }\end{array}$} \\
\hline GCTA & NAS Current Tax & Assets & ICTA & - IFRS & urrent Tax Assets & & & \\
\hline GDTA & NAS Deferred Tax & $\mathbf{x}$ Assets & IDTA & - IFRS I & eferred Tax Assets & & & \\
\hline GCTL & NAS Current Tax & Liabilities & ICTL & - IFRS & urrent Tax Liabilitie & & & \\
\hline GDTL & NAS Deferred Tax & $x$ Liabilities & IDTL & - IFRS I & eferred Tax Liabiliti & & & \\
\hline
\end{tabular}

\section{Summary of the Findings}

To examine the impact of IFRS/IAS (IAS 12) adoption on corporate taxation in Ghana, a quantitative method of study was applied largely. The summary are firstly, a descriptive analyses of the listed entities shown that majority (45.5\%) are financial/ insurance and Information Technology related as in terms of industry placement. Secondly, the impact of post-IFRS adoption on corporate income taxation in Ghana is covered. This research provide evidence of no differences between GNAS and IFRS reported amounts of corporate tax elements of current tax assets, deferred tax assets, current tax liabilities and deferred tax liabilities. The magnitude of these differences and the extent to which individual entities are affected varies considerably. Overall, the paired sample t-test of GNAS and IFRS reported tax amounts showed no differences between IFRS and GNAS computed amounts. 


\section{Mll Macrothink}

International Journal of Accounting and Financial Reporting ISSN 2162-3082 2016, Vol. 6, No. 1

There is however, no enough evidence of statistically significant differences when the differences are tested using the paired sample t-test. Largely, $90.1 \%$ of firms observed did not report any changes to current tax assets. Whiles $94.5 \%, 86.4 \%$ and $59.1 \%$ of observations reported negative changes in deferred tax assets, current liabilities and deferred tax liabilities respectively. In terms of industry sectors, the manufacturing / trading industry saw a positive change of $13 \%$ in current year tax expenses burden whiles the financial / insurance / information technology industry reported a decrease of $13.3 \%$ in current year tax expenses liability.

\section{Conclusions}

Studies in a multiplicity of reporting jurisdictions worldwide have revealed considerable divergence in the impact of IFRS/IAS adoption on taxation. These result raises concern about the potential impact of IFRS/IAS for smaller entities tax burdens. Currently in Ghana the application of IFRS/IAS for small and medium entities (SMEs) has been delayed with proposal that it only be applied to general purpose financial statements of selected SMEs. The results revealed that financial/insurance and information technology firms dominate the Ghana Stock Exchange listing. Industry wise, those in manufacturing and trading saw increases in their corporate current year tax expenses by about $13 \%$ following the adoption of IFRS/IAS. Those however in the financial / insurance and information technology sector saw a decrease in their tax burden of about $13.3 \%$ occasioned by the adoption of IFRS/ IAS.

There were largely (90\%) no differences in current tax assets as reported in GNAS and those restated in IFRS/IAS. However, there was reduction (negative changes) in current tax liabilities, deferred tax assets and deferred tax liabilities as reported in GNAS and restated in IFRS/IAS.It can be concluded that there is no difference in the IFRS/IAS and current year tax expense and current tax assets as restated in the 2008/2007 financial statements and the GNAS current year tax expense and current tax assets reported on the 2007 / 2006 financial statement. Generally, all the corporate tax elements as used in this study indicated large effect size per Cohen (1988) proposed guideline of assigning meanings to the significant values of pair sample t-test.The impact of IFRS/IAS is not widespread as 77.3 percent of firms sample were unaffected in their current year tax expense by the adoption of IFRS/IAS.

Invariably, only 22.7 percent of sample firms were affected in one way of increase or decrease as a result of adopting IFRS/IAS. They were not widely affected because, as it was seen from the notes in the annual reports, most of the firms though adopted IFRS/IAS and restated the prior year figures in IFRS/IAS; they did not adopt IAS 12 as from IFRS/IAS but rather still use income taxes standard from the GNAS. The few entities that adopted IAS 12 instead of the GNAS standard on income taxes reported changes with about $9.1 \%$ companies reporting increases and $13.6 \%$ also reporting decreases in tax burdens.

Conclusively, the adoption of IFRS/IAS led to a few more listed companies paying less taxes and majority not having any changes in their tax burdens following the restatement of accounts from GNAS into IFRS/IAS.Our findings cast doubt on whether the adoption of IFRS/IAS for all other businesses will provide significant benefit or burden in terms of taxation. However, these results need to be interpreted with caution. The impact or effect 
results may reflect one off effects as preparers and users adapt to the new accounting system with its updating nature. Also, the Tax ACT is equally review yearly and as a result events could change in subsequent years. A further and more in-depth longitudinal study could be done to study the trend of tax burdens as well as the pattern of effective tax rates of listed companies since the adoption of IFRS/IAS in Ghana since this study provided mixed results of some increasing, decreasing or staying stagnant.

\section{References}

Alistair, (2010). IFRS. Historical Background. In Essien-Akpan (Ed). IFRS: The Role of Chartered Secretaries and Administrators. 35th Annual Conference of ICSAN. Lagos Sheraton Hotels and Towers. October $26^{\text {th }}$ and $27^{\text {th }}$. Access on $27^{\text {th }}$ July, 2014.

Barth, M. E., Konchitchki, Y., and Landsman, W. R., (2006), 'Cost of capital and financial statement transparency'. Manuscript, Stanford University.

Barth, M. E., Landsman, W. R. and Lang, M. H., (2008). International accounting standards and accounting quality', Journal of Accounting Research, Vol. 46, pp. 467-498.

Bharagava, V. and Shikha, D. (2013), The impact of International Financial Reporting Standards on Financial Statements and Ratios, The International Journal of Management, Vol.2 (2), pp 1-15

Blanchette, M., Racicot, F.-E, Sedzro, K. (2013). IFRS Adoption in Canada: An Empirical Analysis of the Impact on Financial Statements. Certified General Accountants Association of Canada. Access on 26t November, 2015 from http://ppm.cgacanada.org/enca/Documents/Impact\%20of\%20IRFS\%20adoption\%20on\%20Fi nancial\%20Statements\%20-\%20Final\%20-\%20English.pdf

Bradbury, M., and van Zijl, T. (2005). Shifting to International Financial Reporting Standards. University of Auckland Business Review, 7(1), 77-83.

Bushman, R. M., Piotroski, J. \& Smith, A.J. (2006). Capital allocation and timely accounting recognition of economic losses. Working paper, (May), University of Chicago.

Clarkson, P., Hanna, J. D., Richardson, G. D., \& Thompson, R. (2011), The impact of IFRS adoption on the value relevance of book value and earnings, Journal of Contemporary Accounting \& Economics, 7(1), p.1-17.

Cohen, J.W. (1988). Statistical power analysis for the behavioral sciences(2nd edn). Hillsdale, NJ: Lawrence Erlbaum Associates.

Cordazzo, M., (2007). The impact of IAS / IFRS on accounting practices: Evidence from Italia listed Companies.

Daske, H., Hail, L. Leuz, C., and Verdi, R., (2008), 'Mandatory IFRS reporting around the world: Early evidence on the economic consequences', Journal of Accounting Research, Vol. 46(5) pp. 1085-1142.

Duhanxhiu, I., and Kapllani, V., (2012) The relationship between financial and tax accounting 
in Albania, The Romanian Economic Journal, XV (43),pp 45- 60

Eberhartinger, E., and Klostermann, M. (2007). What if IFRS were a Tax Base? New Empirical Evidence from an Austrian Perspective ${ }^{e e}$, Accounting in Europe, 4(2), pp.141-168.

Ernst \& Young (2004), IFRS Impact Report, Ernst \& Young, Southampton.

Faboyede, S., Oyewo,B., Fakile, S., Nwobu, O. (2014), International Financial Reporting Standards (IFRS) Education: Implications For Taxation In Nigeria, EDULEARN14 Proceedings, IATED, pp (4920-4928) access online on $22^{\text {nd }}$ January, 2016 from http://library.iated.org/view/FABOYEDE2014INT

Goodwin, J., and Ahmed, K. (2006). The Impact of International Financial Reporting Standards: Does Size Matter?, Managerial Auditing Journal, 21:460-475.

Goodwin, J., Ahmed, K., \& Heaney, R. (2007). The effects of international financial reporting standards on the accounts and accounting quality of Australian firms: A retrospective study.

Haverals, J. (2005) International Accounting Standards and International Financial Reporting Standards in Belgium: The revaluation of the relationship between accounting and taxation, European Taxation, 45, pp. 199-208.

Haverals, J. (2007) IAS/IFRS in Belgium: Quantitative analysis of the impact on the tax burden of companies, Journal of International Accounting, Auditing and Taxation, 16, pp. 6989.

Hickey, L., Spencer, J., van Zijil, T., and Perry, J. (2003). Adoption of IFRS - Background and Process. Chartered Account Journal of New Zealand, Vol. 82 (6), pp. 4-7.

Hung, M. and Subramanyam, K.R. (2007), "Financial statement effects of adopting international accounting standards: The case of Germany", Review of Accounting Studies, Vol. 12 No. 4, pp. 623-657.

Kwong, J.J., Teixeira, A. and Wang, H. (2005), "Financial reporting impact of NZ IFRS on theNZX50", Chartered Accountants Journal, Vol. 84, No. 6, pp. 8-11.

Larson R.K., Street D.L. (2004). Convergence with IFRS in an expanding Europe: Progress and obstacles identified by large accounting firms 'survey, Journal of International Accounting, Auditing and Taxation, vol. 13, pp. 89-119

Leuz, C., Lins K.V., and Warnock, F. E. (2009). Do foreigners invest less in poorly governed firms? Rev Finance Stu 22, 3245-3285.

Li, S. (2010), 'Does mandatory adoption of international financial reporting standards in the European union reduce the cost of equity capital?', Accounting Review, Vol. 85, pp. 607-636.

Mear, K. M., (2011). Deferred Tax - The effect of the implementation of NZIAS 12: Income Taxes, A thesis presented for a Master of Business Studies (Accountancy) at the Massey University, Albany, New Zealand.

Nkundabanyanga, K. (2004). Advanced Accounting. A practiced approach. 1st Edition: John, 


\section{Macrothink \\ International Journal of Accounting and Financial Reporting \\ ISSN 2162-3082 2016, Vol. 6, No. 1}

H.J. 1987. Business, Contemporary concepts and practices, 9th Edition, prentice Hall International (UK) Ltd, London.

Petreski, M. (2005). The Impact of International Accounting Standard on Firm. Working Paper, School of Business Economics and Management, University American College.

Rainsbury, E., San Diego, J., and Walker, L. (2010). Evidence on the Impact of International Financial Reporting Standards in New Zealand, Paper presented at the Second Quantitative Accounting Research Symposium, 28 May, Auckland, Albany, New Zealand. Access on line on $25^{\text {th }}$ December, 2015 fromhttp://unitec.researchbank.ac.nz/handle/10652/1675

Samuel, F. A., Samuel, F. O., and Obiamaka, N., (2013), The Impact of International Financial Reporting Standards on Taxation, International Journal of Business and Social Sciences, Vol. 4 (10)

Stent, W., Bradbury, M., and Hooks, J. (2010). IFRS in New Zealand: Effects on Financial Statements and Ratios. Pacific Accounting Review, Vol. 22(2), pp. 92-107.

Teixeira, A. (2004), "IFRS - the New Zealand way", Chartered Accountants Journal, Vol. 83, No. 3, pp. 5-8.

Vaughan, G. (2004), "Reporting standards to boost investment", New Zealand Herald, $26^{\text {th }}$ November, available at:http://www.nzherald.co.nz/business/news/article.cfm?c_id=3\&objectid=6500370

Vaughan, G. (2005), "Fletcher set to profit from standards change", The Dominion Post, $28^{\text {th }}$ September, p. 6.

\section{Copyright Disclaimer}

Copyright for this article is retained by the author(s), with first publication rights granted to the journal.

This is an open-access article distributed under the terms and conditions of the Creative Commons Attribution license (http://creativecommons.org/licenses/by/3.0/). 